\title{
Fever among Children with Sickle-Cell Disease: Findings from the General Pediatric Ward of the Owendo Pediatric Hospital in Libreville, Gabon
}

\author{
Jean Koko1,3*, Daniel Gahouma1,3, Simon Ategbo3, Cathérine Seilhan², Armelle Pambou1, \\ André Moussavou ${ }^{3}$

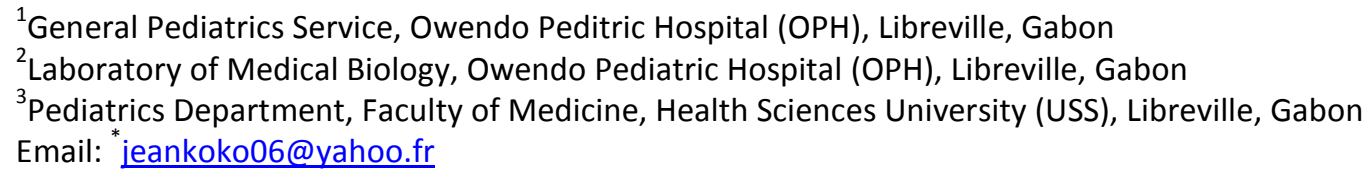

Received 29 August 2014; revised 25 September 2014; accepted 20 October 2014

Academic Editor: Carl E. Hunt, George Washington University School of Medicine and Health Sciences, USA

Copyright (C 2014 by authors and Scientific Research Publishing Inc.

This work is licensed under the Creative Commons Attribution International License (CC BY).

http://creativecommons.org/licenses/by/4.0/

(c) (i) Open Access

\section{Abstract}

Sickle-cell disease (SCD) represents a substantial public health problem in Gabon. Fever is one of the principal reasons for the hospitalization of children afflicted by major sickle-cell disorder, since it can be a clinical reflection of severe infections that have the potential to become life threatening. Objectives: Identification of the main causes of fever in children with SCD in our clinical setting, with the aim of optimizing treatments. Patients and Methods: This is a retrospective study of all the medical files for children with SCD that were admitted to our ward, over a two year period, due to fever $\left(>38.5^{\circ} \mathrm{C}\right)$ lasting more than 24 hours. Only those files that contained at least the following five fundamental medical examinations were retained for further evaluation: Complete Blood Count (CBC), blood smear, blood culture, urine culture and chest X-ray. Out of a total of 118 admissions (103 patients), $87(73.7 \%)$ were due to the incidence of fever. The medical files of 11 patients were deemed to be unusable. Seventy-six episodes of fever were observed among 69 children, of which 42 were male and 27 female (sex ratio of 1.5$)$. Among these, seven (10\%) were admitted twice. Results: The age groups that were most affected included 12 - 18 year-olds (30 cases: $43.5 \%$ ) and 6 - 12 year-olds (26 cases: $37.7 \%$ ). The most common accompanying symptoms were bone and joint pain $(43.4 \%)$, asthenia $(22.4 \%)$, cough $(19.7 \%)$, vomiting $(17 \%)$ and headache $(15.8 \%)$. The specific cause of the fever could not be pinpointed in 29 cases $(38.1 \%)$. Aside from these cases, the main causes of fever were malaria $(30.3 \%)$ and bronchopulmonary infections $(22.4 \%)$. The white blood cell count was $>20,000 / \mathrm{mm}^{3}$ in $47 \%$ of respiratory infections, $43.5 \%$ of the cases involving malaria and $55.2 \%$ of cases of fever with unknown cause. Hemoglobin levels

\footnotetext{
${ }^{*}$ Corresponding author.
}

How to cite this paper: Koko, J., Gahouma, D., Ategbo, S., Seilhan, C., Pambou, A. and Moussavou, A. (2014) Fever among Children with Sickle-Cell Disease: Findings from the General Pediatric Ward of the Owendo Pediatric Hospital in Libreville, Gabon. Open Journal of Pediatrics, 4, 262-268. http://dx.doi.org/10.4236/ojped.2014.44036 
were $<5 \mathrm{~g} / \mathrm{dl}$ for $52.2 \%$ of the cases involving malaria and $22.6 \%$ for those of unknown origin. For four patients, all less than $\mathbf{1 0}$ years of age, the disease was fatal. Conclusion: For the majority of fever episodes, the underlying cause could not be determined. Nonetheless, malaria was identified as one of the principal identifiable causes of fever among children with SDC in Libreville. Treatment for malaria upon admission, and the promotion of preventative measures, therefore seems to be appropriate for our clinical setting. In light of the large number of unresolved cases, systematic prescription of broad-spectrum antibiotics may also be called for.

\section{Keywords}

Sickle-Cell Disease, Fever, Malaria, Acute Lower Respiratory Infections (ALRI), Gabon

\section{Introduction}

Sickle cell disease (SCD) is the most widespread and most serious form of hemoglobin disorders [1]. Sub-Saharan Africa is the most affected area, with an incidence of sickle cell trait ranging from 2 to $30 \%$, depending on the specific region [1]-[4]. According to recent estimates, close to 275,000 afflicted children are born worldwide each year, of which $80 \%$ are in Africa [1]. In Gabon, SCD is a major public health problem, with $24 \%$ of the population carriers of hemoglobin S (HbS) and a $2 \%$ - 3\% level of SS (HbSS) homozygous [5] [6]. Infectious complications are responsible for high rates of morbidity and mortality in SCD patients [4] [7]-[12]. In developed countries, the initiation of effective preventive measures (newborn screening, oral penicillin prophylaxis, pneumococcal and Haemophilus type b immunization) has resulted in the dramatic reduction in these rates [7] [12] [13]. This preventive strategy remains not easily accessible in sub-Saharan Africa, except for some pilot projects [14] [15]. Fever may be the expression of these infections, as shown by several authors [16]-[20], but to our knowledge no similar studies have been conducted to date in Gabon. Also in case of occurrence of fever, the physician is confronted with the haunting of a serious infection requiring prompt and aggressive treatment. The aim of this study was to determine the main causes of fever in children with sickle cell disease in our context, in order to optimize therapeutic management.

\section{Patients and Methods}

Records of children with sickle cell disease, hospitalized in our department for fever (axillary temperature > $38.5^{\circ} \mathrm{C}$ ) evolving for more than 24 hours over a period of 24 months, were retrospectively analyzed. They were known sickle cell patients, the diagnosis having been made previously, most often during the development of acute complications. The hospital receives patients unselected, brought directly to the emergency room by the parents, or sent by other health facilities instead. No specific monitoring is organized there. Children are hospitalized alone without escorts. We selected only those files containing at least the following five tests: Complete Blood Count (CBC), blood smear (BS) to detect malaria parasites, urine culture, blood culture $(\geq 1)$, and chest X-ray. A lumbar puncture was performed in cases of meningeal syndrome or other signs that indicated neurological issues. Out of a total of 118 admissions (103 patients), 87 (73.7\%) were due to the incidence of fever. From the latter group, records from eleven patients were deemed to be unusable (incomplete files). Seventy-six episodes of fever were observed among 69 children (seven children were admitted twice or more). There were 42 boys and 27 girls, resulting in a gender ratio of 1.5. All of the patients were homozygous SS. None were receiving regular health checks and there was no documentable evidence of specific preventative measures (e.g. oral penicillin, pneumococcal and Haemophilus influenzae type b vaccination). The protocol of care in emergency included a dual probabilistic antibiotic treatment cefotaxime + gentamicin in addition to quinine salt perfusion. Transfusion of packed red blood cells was performed in all patients with hemoglobin $<5 \mathrm{~g} / \mathrm{dl}$. Ethical approval for the study was obtained from the research and ethics committee of the Faculty of Medicine of the Health Sciences University, Libreville, Gabon. Statistical analyses were performed using the Chi-squared distribution and Fisher's exact test for measures $<3$. A p-value of $<0.05$ was considered to be significant.

\section{Results}

The most represented age groups were 12 - 18 year-olds (30 cases: 43.5\%) and 6 - 12 year-olds (26 cases: 37.7\%) 
(Figure 1). The most common associated symptoms (Table 1) were bone and joint pain (43.4\%), weakness (22.4\%) and cough (19.7\%). Table 2 lists the causes of the fever. Three patients (3.9\%) had urinary tract infection; the isolated microbes being Escherichia Coli (two cases) and Klebsiella pneumoniae (one case). The cause of the fever could only be clearly established for 29 of the cases (38.1\%). The blood cultures were positive six times (8.7\%); Streptococcus pneumoniae (two cases) and Haemophilus influenzae (two cases) were all associated with pulmonary impairment. Klebsiella pneumoniae (one case) and Salmonella spp (one case) were the other organisms that were detected. Lumbar punctures, which were carried out 8 times (11.6\%), were normal: for one child undergoing convulsions, five children between the ages of 6 and 12 who had headaches and back pain, and two children of three and four years of age, respectively, who experienced vomiting and weakness. Analysis of symptoms associated with the fever (Table 1$)$ indicated a significant difference $(p=0.002)$ between respiratory tract infections and malaria in terms of coughing fits. White blood cell counts were $>20,000 / \mathrm{mm}^{3}$ for $47 \%$ of the cases involving respiratory infections, $43.5 \%$ of the malaria cases and $55.25 \%$ of the cases of fever with unknown origin (Table 3); and there was no significant difference between these values. Four fatalities were documented (5.8\%): two cases of acute anemia involving malaria in a two year old girl and a seven year old boy, one case of Salmonella spp septicemia for a four year old boy, and one case of a boy, aged 5, who was undergoing convulsions and for whom the cause could not be determined.

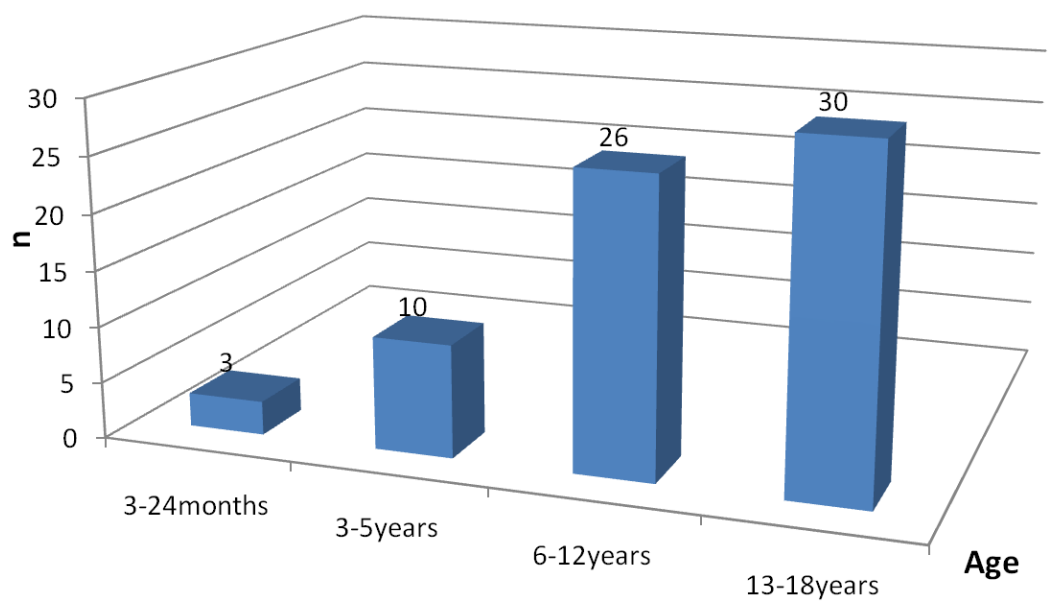

Figure 1. Age distribution of the 69 sickle cell disease patients.

Table 1. Functional signs depending on the cause of fever in the 69 children with sickle cell disease admitted to the Owendo Pediatric Hospital (HPO).

\begin{tabular}{|c|c|c|c|c|c|c|c|}
\hline $\begin{array}{c}\text { Causes } \\
\text { symptoms }\end{array}$ & $\begin{array}{c}\text { Malaria } \\
\mathrm{n}=23(\%)\end{array}$ & $\begin{array}{l}\text { Bronchopulmonary } \\
\text { infection } n=17(\%)\end{array}$ & $\begin{array}{c}\text { Undetermined } \\
\text { causes } n=29(\%)\end{array}$ & $\begin{array}{c}\text { Urinary tract } \\
\text { infection } n=3(\%)\end{array}$ & $\begin{array}{l}\text { Osteomyelitis } \\
\mathrm{n}=2(\%)\end{array}$ & $\begin{array}{c}\text { Total } \\
\text { (\%) }\end{array}$ & p-value \\
\hline Weakness & $8(34.8)^{*}$ & 2 (11.8) & $4(13.8)^{*}$ & $1(33.3)$ & $2(100)$ & $17(22.4)$ & 0.07 \\
\hline Headache & $4(17.4)$ & $2(11.8)$ & $5(17.2)$ & $1(33.3)$ & $0(0.0)$ & $12(15.8)$ & \\
\hline $\begin{array}{l}\text { Abdominal } \\
\text { pain }\end{array}$ & $5(21.7)$ & $2(11.8)$ & $3(10.3)$ & $0(0.0)$ & $0(0.0)$ & 10 (13.1) & \\
\hline $\begin{array}{l}\text { Bone and } \\
\text { joint pain }\end{array}$ & $7(30.4)^{*}$ & $7(41.2)$ & $15(51.7)^{*}$ & 2 (66.7) & $2(100)$ & 33 (43.4) & 0.12 \\
\hline Back pain & $0(0.0)$ & $0(0.0)$ & $4(13.8)$ & $1(33.3)$ & $0(0.0)$ & $5(6.6)$ & \\
\hline Chest pain & $0(0.0)$ & $2(11.8)$ & $3(10.3)$ & $1(33.3)$ & $0(0.0)$ & $6(7.9)$ & \\
\hline Cough & $4(17.4)^{*}$ & $11(64.7)^{*}$ & $0(0.0)$ & $0(0.0)$ & $0(0.0)$ & 15 (19.7) & 0.002 \\
\hline Vomiting & $5(21.7)$ & $2(11.8)$ & $5(17.2)$ & $1(33.3)$ & $0(0.0)$ & $13(17.1)$ & \\
\hline Vertigo & $2(8.7)$ & $0(0.0)$ & $0(0.0)$ & $0(0.0)$ & $0(0.0)$ & $2(2.9)$ & \\
\hline Convulsions & $0(0.0)$ & $0(0.0)$ & $1(3.4)$ & $0(0.0)$ & $0(0.0)$ & $0(0.0)$ & \\
\hline
\end{tabular}

*Compared values. 
Table 2. Causes of fever among the 69 children with SCD who were admitted to the OPH.

\begin{tabular}{lcc}
\hline \multicolumn{1}{c}{ Causes } & $\mathbf{n}$ & \% \\
\hline Bronchopulmonary infections & 17 & 22.4 \\
-Bronchopneumonia & 11 & 14.5 \\
-Pneumonia & 6 & 7.9 \\
Malaria & 23 & 30.3 \\
Bone and joint infections & 2 & 2.6 \\
Urinary tract infections & 3 & 3.9 \\
Bacteremia & 6 & 8.7 \\
-Salmonella spp & 1 & 1.3 \\
-Streptococcus pneumoniae & 2 & 2.6 \\
-Haemophilus influenzae & 2 & 2.6 \\
-Klebsiella pneumoniae & 1 & 1.3 \\
Hepatitis B & 1 & 1.3 \\
Undetermined causes & 29 & 38.1 \\
Total & $\mathbf{7 6}$ & $\mathbf{1 0 0}$ \\
\hline
\end{tabular}

Table 3. Levels of white blood cells and hemoglobin according to the principal causes of fever among the 69 children with SCD admitted to the Owendo Pediatrics Hospital.

\begin{tabular}{|c|c|c|c|c|c|c|}
\hline Causes & $\begin{array}{c}\text { Respiratory } \\
\text { infections } \\
\mathbf{n}=17(\%)\end{array}$ & $\begin{array}{c}\text { Malaria } \\
n=23(\%)\end{array}$ & $\begin{array}{c}\text { Undetemined } \\
\text { causes } n=29(\%)\end{array}$ & $\begin{array}{c}\text { Urinary tract } \\
\text { infection } n=3(\%)\end{array}$ & $\begin{array}{c}\text { Bone and joint } \\
\text { infections } n=2(\%)\end{array}$ & p-value \\
\hline \multicolumn{7}{|l|}{ Leukocytes } \\
\hline$<10000 / \mathrm{mm}^{3}$ & $1(5.9)$ & $3(13)$ & $0(0.0)$ & $0(0.0)$ & $0(0.0)$ & 0.63 \\
\hline $10000-20000 / \mathrm{mm}^{3}$ & $8(47)^{*}$ & $10(43.5)^{*}$ & $13(44.8)$ & $1(33.3)$ & $1(50)$ & \\
\hline$>20000 / \mathrm{mm}^{3}$ & $8(47)^{*}$ & $10(43.5)^{*}$ & $16(55.2)$ & $2(66.6)$ & $1(50)$ & \\
\hline \multicolumn{7}{|l|}{ Hemoglobin } \\
\hline$\leq 5 \mathrm{~g} / \mathrm{dl}$ & $4(23.5)$ & $12(52.2)^{*}$ & $8(27.6)^{*}$ & $1(33.3)$ & $1(50)$ & \\
\hline$>5 \mathrm{~g} / \mathrm{dl}$ & $13(76.5)$ & $11(47.8)^{*}$ & $21(72.4)^{*}$ & $2(66.6)$ & $1(50)$ & 0.07 \\
\hline
\end{tabular}

*Compared values.

\section{Discussion}

The limitations of this study are inherent to its retrospective nature: no inclusion of patients seen in outpatient, many incomplete records and many cases of undetermined cause. A prospective study would refine our results that nevertheless provide valuable information.

Bacterial infections represent the main complication associated with SCD, resulting in elevated morbidity and mortality rates [4] [7]-[12]. Therefore, in case of fever, most protocols of care as well as international recommendations advocate routine prescription of broad-spectrum antibiotics [7] [10]-[12] [16]-[20]. It is however difficult to implement such treatment in Africa since these drugs are expensive and are not always readily available in the health facilities. The objective of this study was to assess the causes of fever in Libreville, with the aim of optimizing the administration of antibiotics. In light of the large number of cases of unknown origin (38.1\%) and the frequency of respiratory and other infections (22.4\%), it seems clear that systematic administration of antibiotics is advisable for patients in Gabon with SCD. Malaria remains, however, the main cause of fever that can be definitively associated with SCD, since it occurred in $30.3 \%$ of our patient cohort. This rate is higher than that observed by Rahimy et al. at Cotonou (6.7\%) [14], but this involved a cohort of monitored 
children who were receiving anti-malarial prophylaxis [13]. On the other hand, Gabon is situated in an area where malaria is holo-endemic. Transmission of the parasite is hence stable and continuous throughout the year, and this may explain these rates. While it is generally accepted that the hemoglobin $\mathrm{S}$ trait has a protective role against severe forms of malaria [2] [21] [22], it is also known that the latter exacerbates the anemia due to hyperhemolysis and presents a trigger for vaso-occlusion crisis (VOC) [7] [21]. Therefore, 12 of the 23 patients (52.2\%) afflicted by malaria had severe anemia $(\mathrm{Hb}<5 \mathrm{~g} / \mathrm{dl})$, hence requiring a transfusion (Table 3). A similar frequency (54.4\%) was found by Ntetani Aloni et al. in Kinshasa [23]. Among these, we encountered two deaths, which confirm the observations made by McAuley et al. in Kenya [24]. Since the abandonment of the anti-malarial chemoprophylaxis in Gabon because of high levels of chloroquine resistance, the insecticide treated bed net is now the only effective preventive measure recommended.

Bronchopulmonary infections were the second cause of fever in our study (22.4\%). These typically are major determinants of morbidity and mortality in sickle cell disease [7]. They accounted for $42.8 \%$ of infections we observed in a previous report [8] and $40.4 \%$ of cases in Libreville as reported by Thuillez et al. [6]. In a study by Wierenga et al., acute chest syndrome (ACS) was the second leading cause of fever with $21.8 \%$ and was the only pulmonary involvement [17]. The ACS is conventionally defined as the association of chest pain with shortness of breath and a recent radiological abnormalities (infiltrate), all against a backdrop of fever [7] [17]. This frequently requires treatment in the intensive care unit. Although the distinction between a beginning ACS and a simple pneumonia is often difficult, we took the diagnosis of pneumonia and bronchopneumonia given the absence of dyspnea in our patients and the favorable outcome with conventional treatment. Streptococcus pneumoniae and Haemophilus influenzae type b are the most frequently implicated pathogens, and to a lesser degree atypical bacteria such as Mycoplasma pneumonia. As we will see later, many studies note the effectiveness of antibiotic prophylaxis with oral penicillin and vaccination in the prevention of these diseases [7] [12] [14] [25] [26]. The infection can also be caused by viruses, which does not diminish its potential severity in which it can trigger a vaso-occlusive crisis through fever, hypoxia and dehydration, all three factors of sickling [7].

Urinary tract infections constitute another frequent cause of fever in children with SCD. We only found three cases, or 3.9\%. This is similar to the $2.4 \%$ incidence observed by Wierenga et al. in Jamaica [17], but considerable lower than the $26 \%$ noted by Mava et al. in Nigeria [27]. In a previous investigation undertaken at our ward, $42.8 \%$ of the observed bacterial infections were urinary tract infections [8].

Bacteremia represents the main threat to children with SCD. We detected six cases (8.7\%) of which one was septicemia, compared to 6.1\% for Wierenga et al. in Jamaica [17], 6.6\% for Williams et al. in Kenya [25] or 0.8\% for Baskin et al. in Boston [26]. This low incidence that we observed is probably due to the self-administration of antibiotics, which is a common practice in Libreville that is often not revealed by parents for fear of being reprimanded by the health care staff. In our Hospital, on the other hand, since children are admitted on their own, their mothers often prefer other forms of health care. It is also possible that, due to lack of parental knowledge, fever in some young children goes undiagnosed, causing them to perish without even being admitted to Hospital. All of these reasons can explain the low proportion of children less than 5 years old in our study. In addition to being the most commonly encountered, Streptococcus pneumonia, Haemophilus influenzae type b and Salmonella spp are also the most dreaded bacteria [7] [11] [25]. Thanks to the combined effects of oral penicillin and a range of vaccines, a discrete decline in invasive infections has been observed in recent years in the developed world [7] [12] [13] [26]-[28]. In Gabon, as elsewhere in sub-Saharan Africa, this preventative strategy does not exist due to inefficiencies in the health care system and due to the cost of the antibiotics and vaccines. In keeping with opinions expressed by other authors [13] [27]-[29], we believe that a preventative approach remains attainable in Africa, provided that proactive measures are taken to ensure systematic neonatal screening and to provide ready access to vaccines and oral penicillin, similar to what has been done successfully at Cotonou in Benin [14]. In the meantime, despite the availability of only minimal resources, it is nonetheless entirely possible to implement medical care that will improve the outcome for youngsters in Gabon who are afflicted with SCD.

In keeping with the low incidence of bacteremia, only two cases (2.6\%) of bone and joint infections were detected, and none case involved meninges. Our previous investigations [8] [9] had already demonstrated that these locations were affected relative infrequently among individuals in Gabon with SCD. These observations were substantiated by Thuillez et al. in a cohort of nearly 300 patients [6].

For more than one-third of the cases (38.1\%), none cause could be identified. This differs from the $16.7 \%$ re- 
ported in Benin [14]. Nearly half of these patients experienced severe bone and joint pain (Table 1). Analysis of white blood cells and the level of hemoglobin failed to provide significant clues regarding the disease etiology (Table 3). Bégué et al. [7] reported that the elevated fever did not always correspond to an underlying infection. Rather, it was associated with complications such as pulmonary thrombosis and multiple bone infarcts. For the patient cohort in Jamaica [17], these painful bouts occurred in $27.3 \%$ of cases, and they were deemed to be the sole cause of the fever in $12.1 \%$ of the cases. It is now known that the occurrence of a bone infarct induces inflammatory cytokine production and other pyrogenic products that are responsible for elevated body temperatures [7] [17]. In the other cases (aside from VOCs), like Wierenga et al. [17] we believe that these high fevers involve infections of viral origin or atypical microbes that are not included in our hospital's diagnostic screening protocol.

\section{Conclusion}

Fever remains a common reason for consultation in sickle cell child. It can be an expression of a serious infection requiring emergency care. In Africa more than elsewhere, the risk of infection is an ongoing concern for medical staff. The highlight of our study is that none etiology was found in the vast majority of cases. However, bronchopulmonary infections and malaria occupy a significant place in Libreville. Given that definitive exclusion of a bacterial infection is not possible, we believe that the prescription of broad-spectrum antibiotics by parenteral route remains a wise precaution, despite the high cost of this therapeutic strategy.

\section{Conflict of Interest}

None.

\section{References}

[1] Modell, B. and Darlison, M. (2008) Global Epidemiology of Haemoglobin Disorders and Derived Service Indicators. Bulletin of the World Health Organization, 86, 480-487. http://dx.doi.org/10.2471/BLT.06.036673

[2] Labie, D. and Elion, J. (2010) La drépanocytose: Problème de l’Afrique. Médecine Tropicale, 70, 449-453.

[3] Diagne, I., Diagne-Gueye, N.D.R., Signate-Sy, H., et al. (2003) Prise en charge de la drépanocytose chez l'enfant en Afrique: expérience de la cohorte de l'hôpital d'enfants Albert Royer de Dakar. Médecine Tropicale, 63, 513-520.

[4] Grosse, S.D., Odame, I., Atrash, H.K., Amendah, D.D., Piel, F.B. and Williams, T.N. (2011) Sickle Cell Disease in Africa. A Neglected Cause of Early Childhood Mortality. American Journal of Preventive Medicine, 41, S398-S405.

[5] Gendrel, D., Nardou, M. and Gendrel, C. (1991) Le poids de la drépanocytose dans un service de pédiatrie africain. In: Galactéros, F. and Dormont, S., Eds., Drépanocytose et santé publique, Inserm/Centre international de l'enfance, Paris, 153-154.

[6] Thuillez, V., Ditsambou, V., Mba, J.R. Mba Meyo, S. and Kitengue, J. (1996) Aspects actuels de la drépanocytose chez l'enfant au Gabon. Archives de Pédiatrie, 3, 668-674. http://dx.doi.org/10.1016/0929-693X(96)87087-4

[7] Bégué, P. and Castello-Herbreteau, B. (2001) Infections graves chez l'enfant drépanocytaire: Aspects cliniques et prévention. Archives de Pédiatrie, 8, 732S-741S. http://dx.doi.org/10.1016/S0929-693X(01)80189-5

[8] Koko, J., Kani, F., Reymond-Yéni, A., Onewin-Andjanga, G., Moussavou, A. and Gahouma, D. (1999) Infections bactériennes chez l'enfant drépanocytaire à Libreville. Archives de Pédiatrie, 6, 1131-1132. http://dx.doi.org/10.1016/S0929-693X(00)86994-8

[9] Koko, J., Dufillot, D., M’ba-Meyo, J., Gahouma, D. and Kani, F. (1998) Mortalité des enfants drépanocytaires dans un service de pédiatrie en Afrique Centrale. Archives de Pédiatrie, 5, 965-969. http://dx.doi.org/10.1016/S0929-693X(98)80003-1

[10] Wethers, D.L. (2000) Sickle Cell Disease in Childhood: Part II. Diagnosis and Treatment of Major Complications and Recent Advances in Treatment. American Family Physician, 62, 1309-1314.

[11] Ramakrishnan, M., Moïsi, J.C., Klugman, K.P., Iglesias, J.M., Grant, L.R., Mpoudi-Etame, M. and Levine, O.S. (2010) Increased Risk of Invasive Bacterial Infections in African People with Sickle-Cell Disease: A Systematic Review and Meta-Analysis. Lancet Infectious Diseases, 10, 329-337. http://dx.doi.org/10.1016/S1473-3099(10)70055-4

[12] Di Nuzzo, D.V.P. and Fonseca, S.F. (2004) Sickle Cell Disease and Infection. Jornal de Pediatria (Rio de Janeiro), 80, 347-354. http://dx.doi.org/10.2223/JPED.1218

[13] Chakravorty, S. and Williams, T.N. (2014) Sickle Cell Disease: A Neglected Chronic Disease of Increasing Global 
Health Importance. Archives of Disease in Childhood, Published Online.

[14] Rahimy, M.C., Gangbo, A., Ahouignan, G., Anagonou, S., Boco, V. and Alihonou, E. (1999) Outpatient Management of Fever in Children with Sickle Cell Disease (SCD) in an African Setting. American Journal of Hematology, 62, 1-6. http://dx.doi.org/10.1002/(SICI)1096-8652(199909)62:1<1::AID-AJH1>3.0.CO;2-C

[15] Tshilolo, L., Aissi, L.M., Lukusa, D., Kinsiama, C., Wembonyama, S., Gulbis, B. and Vertongen, F. (2009) Neonatal Screening for Sickle Cell Anaemia in the Democratic Republic of the Congo: Experience from a Pioneer Project on 31 204 Newborns. Journal of Clinical Pathology, 62, 35-38. http://dx.doi.org/10.1136/jcp.2008.058958

[16] McIntosh, S., Rooks, Y., Ritchey, A.K. and Pearson, H.A. (1980) Fever in Young Children with Sickle Cell Disease. The Journal of Pediatrics, 96, 199-204. http://dx.doi.org/10.1016/S0022-3476(80)80802-X

[17] Wierenga, K.J.J., Hambleton, I.R., Wilson, R.M., Alexander, H., Serjeant, B.E. and Serjeant, G.R. (2001) Significance of Fever in Jamaican Patients with Homozygous Sickle Cell Disease. Archives of Disease in Childhood, 84, 156-159. http://dx.doi.org/10.1136/adc.84.2.156

[18] Narang, S., Fernandez, I.D., Chin, N., Lerner, N. and Weinberger, G.A. (2012) Bacteremia in Children with Sickle Hemoglobinopathies. Journal of Pediatric Hematology/Oncology, 34, 13-16. http://dx.doi.org/10.1097/MPH.0b013e318240d50d

[19] Bansil, N.H., Kim, T.Y., Tieu, L. and Barcega, B. (2013) Incidence of Serious Bacterial Infections in Febrile Children with Sickle Cell Disease. Clinical Pediatrics (Philadelphia), 52, 661-666. http://dx.doi.org/10.1177/0009922813488645

[20] Shihabuddin, B.S. and Scarfi, C.A. (2014) Fever in Children with Sickle Cell Disease: Are All Fevers Equal? Journal of Emergency Medicine, 47, 395-400. http://dx.doi.org/10.1016/j.jemermed.2014.06.025

[21] Gendrel, D., Kombila, M., Nardou, M., Gendrel, C., Djouba, F. and Richard-Lenoble, D. (1991) Protection against Plasmodium falciparum Infection in Children with Hemoglobin S. The Pediatric Infectious Disease Journal, 10, 620621. http://dx.doi.org/10.1097/00006454-199108000-00013

[22] Williams, T.N., Mwangi, T.W., Wambua, S., Alexander, N.D., Kortok, M., Snow, R.W. and Marsh, K. (2005) Sickle Cell Trait and the Risk of Plasmodium falciparum Malaria and Other Childhood Diseases. The Journal of Infectious Diseases, 192, 178-186. http://dx.doi.org/10.1086/430744

[23] Aloni, M.N., Tshimanga, B.K., Ekulu, P.M., Ehungu, J.L.G. and Ngiyulu, R.M. (2013) Malaria, Clinical Features and Acute Crisis in Children Suffering from Sickle Cell Disease in Resource-Limited Settings: A Retrospective Description of 90 Cases. Pathogens and Global Health, 107, 198-201. http://dx.doi.org/10.1179/2047773213Y.0000000089

[24] McAuley, C.F., Webb, C., Makani, J., Macharia, A., Uyoga, S., Opi, D.H., et al. (2010) High Mortality from Plasmodium falciparum Malaria in Children Living with Sickle Cell Anemia on the Coast of Kenya. Blood, 116, 16631668. http://dx.doi.org/10.1182/blood-2010-01-265249

[25] Williams, T.N., Uyoga, S., Macharia, A., Ndila, C., McAuley, C.F., Opi, D.H., et al. (2009) Bacteraemia in Kenyan Children with Sickle-Cell Anaemia: A Retrospective Cohort and Case-Control Study. The Lancet, 374, 1364-1370. http://dx.doi.org/10.1016/S0140-6736(09)61374-X

[26] Baskin, M.N., Goh, X.L., Heeney, M.M. and Harper, M.B. (2013) Bacteremia Risk and Outpatient Management of Febrile Patients with Sickle Cell Disease. Pediatrics, 131, 1035-1041. http://dx.doi.org/10.1542/peds.2012-2139

[27] De Montalembert, M. and Tshilolo, L. (2007) Les progrès thérapeutiques dans la prise en charge de la drépanocytose sont-ils applicables en Afrique subsaharienne? Médecine Tropicale, 67, 612-616.

[28] Quinn, C.T., Rogers, Z.R. and Buchanan, G.R. (2004) Survival of Children with Sickle Cell Disease. Blood, 103, 40234027. http://dx.doi.org/10.1182/blood-2003-11-3758

[29] Ware, R.E. (2013) Is Sickle Cell Anemia a Neglected Tropical Disease? PloS Neglected Tropical Diseases, 7, e2120. http://dx.doi.org/10.1371/journal.pntd.0002120 
Scientific Research Publishing (SCIRP) is one of the largest Open Access journal publishers. It is currently publishing more than 200 open access, online, peer-reviewed journals covering a wide range of academic disciplines. SCIRP serves the worldwide academic communities and contributes to the progress and application of science with its publication.

Other selected journals from SCIRP are listed as below. Submit your manuscript to us via either submit@scirp.org or Online Submission Portal.
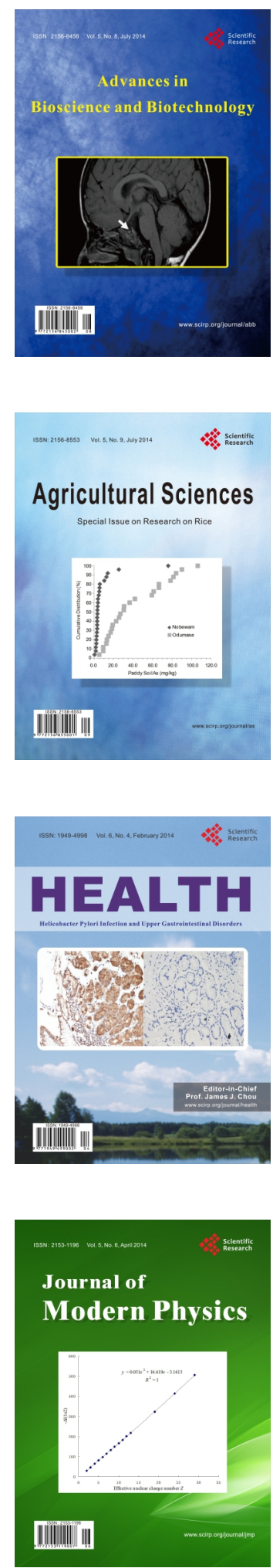
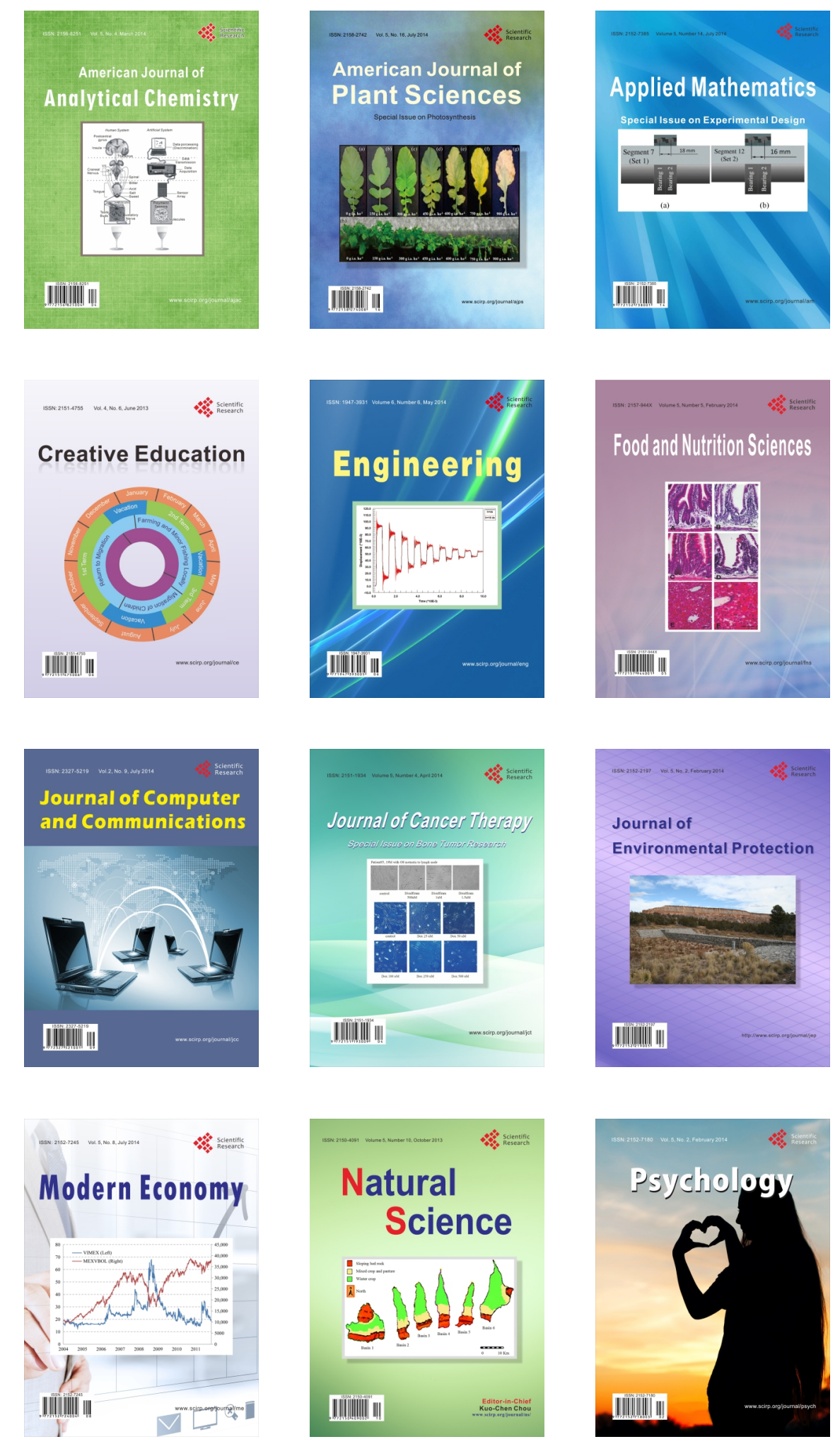